\title{
Opleiden vandaag, zorgen voor morgen
}

\author{
Citation for published version (APA):
}

Stassen, L. P. (2013). Opleiden vandaag, zorgen voor morgen. Maastricht University. https://doi.org/10.26481/spe.20130412ls

Document status and date:

Published: 12/04/2013

DOI:

$10.26481 /$ spe.20130412ls

Document Version:

Publisher's PDF, also known as Version of record

\section{Please check the document version of this publication:}

- A submitted manuscript is the version of the article upon submission and before peer-review. There can be important differences between the submitted version and the official published version of record.

People interested in the research are advised to contact the author for the final version of the publication, or visit the DOI to the publisher's website.

- The final author version and the galley proof are versions of the publication after peer review.

- The final published version features the final layout of the paper including the volume, issue and page numbers.

Link to publication

\footnotetext{
General rights rights.

- You may freely distribute the URL identifying the publication in the public portal. please follow below link for the End User Agreement:

www.umlib.nl/taverne-license

Take down policy

If you believe that this document breaches copyright please contact us at:

repository@maastrichtuniversity.nl

providing details and we will investigate your claim.
}

Copyright and moral rights for the publications made accessible in the public portal are retained by the authors and/or other copyright owners and it is a condition of accessing publications that users recognise and abide by the legal requirements associated with these

- Users may download and print one copy of any publication from the public portal for the purpose of private study or research.

- You may not further distribute the material or use it for any profit-making activity or commercial gain

If the publication is distributed under the terms of Article $25 \mathrm{fa}$ of the Dutch Copyright Act, indicated by the "Taverne" license above, 
Prof. dr. Laurents P.S. Stassen

Faculty of Health, Medicine and Life Sciences

\section{Opleiden vandaag, zorgen voor morgen}




\section{INHOUD ORATIE}

\section{"OPLEIDEN VANDAAG, ZORGEN VOOR MORGEN"}

\section{Inleiding}

Hooggeleerde pro-rector, geachte decaan, leden van het College vanToezicht, leden van de Raad van Bestuur van het MaastrichtUMC, hooggeleerde gasten, beste aanwezigen,

De Gastrointestinale chirurgie is een heel mooi vak. Het is dankbaar en uitdagend om met steeds nieuwe mogelijkheden zieke mensen beter te kunnen maken. Het is een dagelijks plezier om met vele werkers in deze zorg hoge kwaliteit te leveren.

Dit had puur de titel van mijn leerstoel kunnen zijn: gastrointestinale chirurgie. Het uitoefenen van dat vak is een mooie opdracht als hoogleraar. Maar dan had er toch iets essentieels ontbroken. De geneeskunde blijft niet vanzelf mooi en hoogstaand. Dit kan alleen door kennis en kunde over te brengen op aankomend specialisten en studenten geneeskunde.

Daarom is de ondertitel van mijn leerstoel "Opleiding en onderwijs". En de titel van mijn oratie: opleiden vandaag, en daardoor zorgen voor morgen.

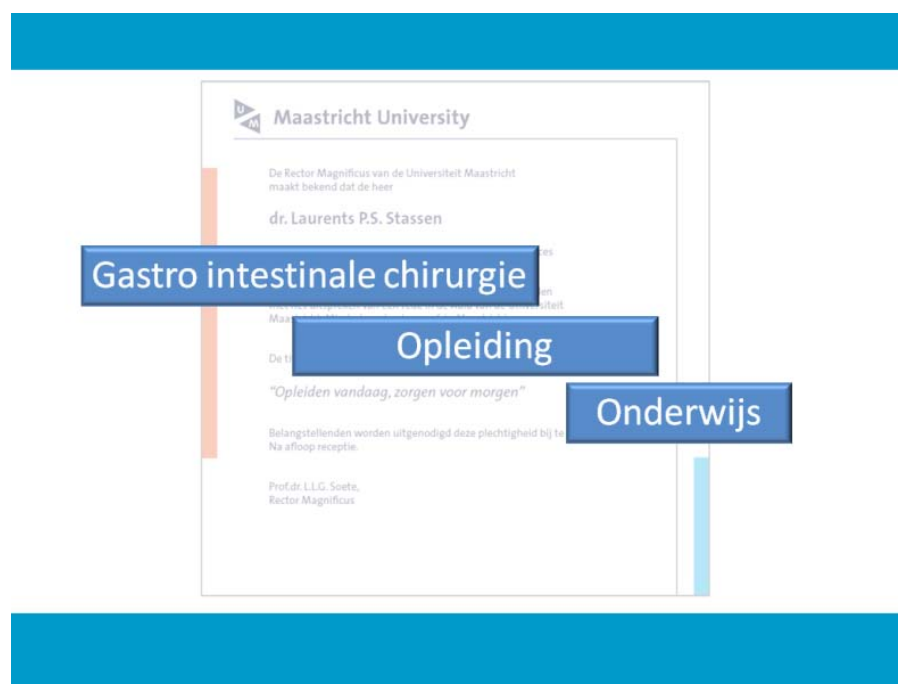

U zult deze onderwerpen alle drie in mijn rede terugvinden: gastrointestinale chirurgie, opleiding en onderwijs.

Ik zal u eerst een beeld geven van belangrijke ontwikkelingen in de gastrointestinale chirurgie, met name die waar ik bij betrokken was en hoop te blijven. En hun invloed op de opleiding tot specialist. Ook ga ik in op de consequenties die veranderingen in de zorg en de maatschappij op de opleiding tot medisch specialist hebben. Tot slot besteed ik aandacht aan het onderwijs: de opleiding tot basisarts.

In de titel van mijn oratie staat zorgen voor morgen. Door op te leiden vandaag willen wij goede zorg morgen garanderen. Toch zal ik ook een ander soort van zorgen met $u$ delen: zorgen over morgen. Niet alle ontwikkelingen stemmen even optimistisch. Om goed beleid en een goede opleiding te maken moeten wij ook stilstaan bij bedreigingen en de jonge generatie betrekken in de discussie om hen zo goed mogelijk voor te bereiden op de toekomst.

\section{DE GASTROINTESTINALE CHIRURGIE OFWEL DE MAAGDARMCHIRURGIE.}




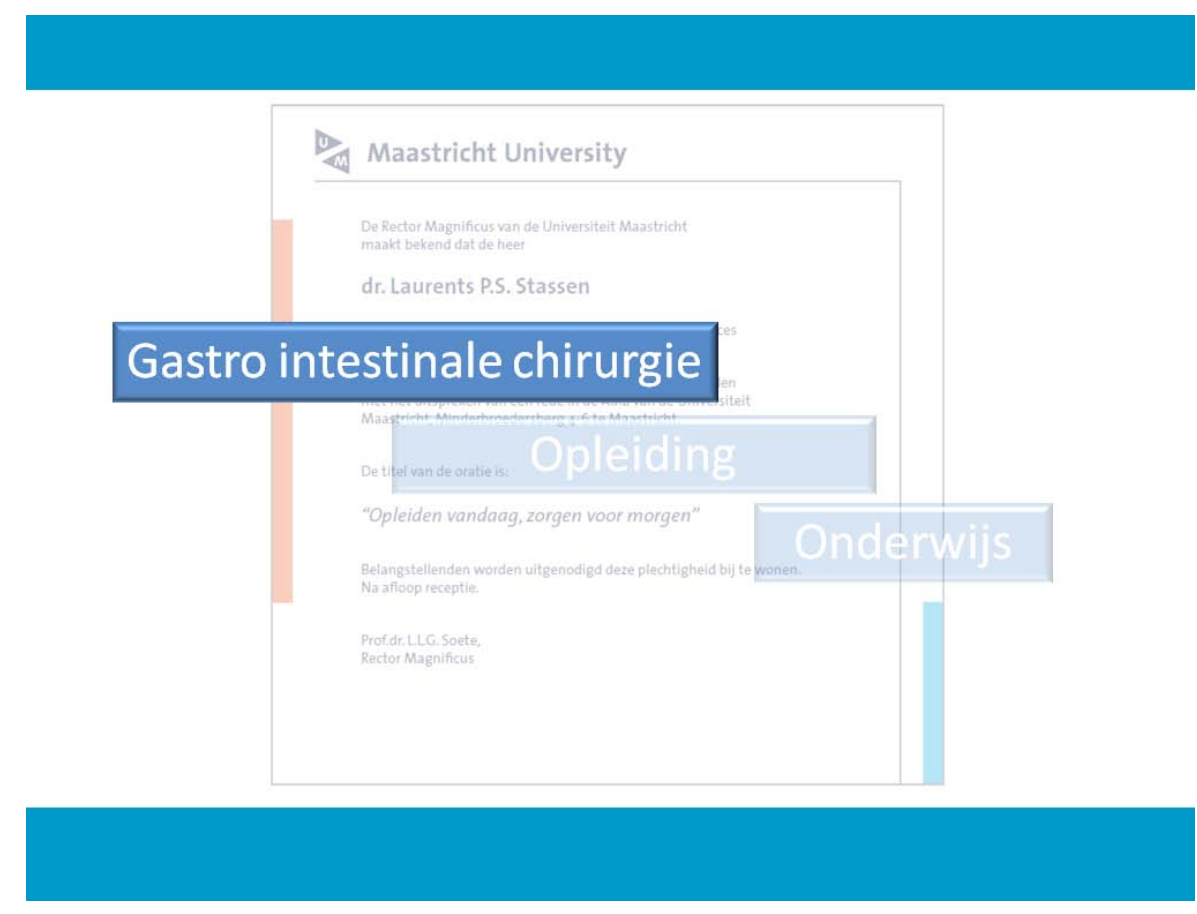

Ik wil met u twee belangrijke hoofdstukken bespreken uit deze chirurgie: de grote en de kleine operaties.

Met grote operaties bedoel ik hoogrisico laagvolume ingrepen. Dit zijn ingrepen die niet vaak uitgevoerd worden en tegelijk lastig zijn en daardoor een verhoogde kans op complicaties geven. In deze zorg hebben zich het laatste decennium belangrijke ontwikkelingen afgespeeld. En deze zijn nog niet ten einde. We zouden kunnen spreken van een revolutie.

Een tweede revolutie heeft zich afgespeeld op het gebied van de kleine operaties. Hiermee bedoel ik de minimaal invasieve chirurgie, de kijkoperatie. Deze volledig nieuwe operatietechniek heeft de chirurgische wereld radicaal veranderd. Vooral in de maagdarm chirurgie wordt de kijkoperatie techniek veel gebruikt. Ik zal spreken over voordelen en risico's, kwaliteit, opleiding en onderzoek op dit terrein.

\section{Grote operaties}

Allereerst de grote operaties.

Ik leerde deze vooral in mijn fellowship in het toenmalige Dijkzigt ziekenhuis in Rotterdam, van mijn leermeesters Huug Tilanus en Ruud Schouten. 


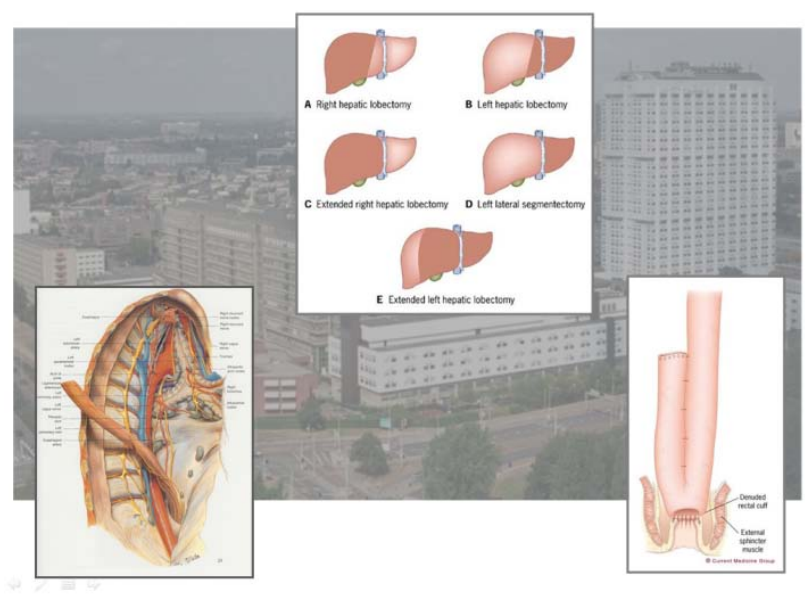

Ik leerde onder meer slokdarmchirurgie, leverchirurgie, en het verrichten van ileoanale pouches.

Hoe mooi ook om te doen, het gebied van grote operaties is ook terrein waar gevaar in schuilt. Grote operaties kennen grote complicaties. Alleen een ingespeeld team, met voldoende expertise bij alle leden, kan deze tot een minimum beperken.

Na mijn toetreden tot de maatschap in Delft werd in de dienst van mij verwacht dat ik een acuut aneurysma (een gesprongen hoofdlichaamsslagader) zou opereren. Ik vond dit geen goed plan. Dit is immers een ingreep met hoge risico's, zelfs voor een vaatchirurg. Dit was de aanzet tot het instellen van een specifiek vaatchirurgische dienst in onze maatschap waarmee deze zijn tijd vooruit was.

We zijn gekomen op de relatie tussen ervaring en uitkomst, en volume en uitkomst. Anno nu is dit gesneden koek: zeldzame chirurgie wordt alleen gedaan door ziekenhuizen en chirurgen met de nodige ervaring. Maar destijds, ruim 15 jaar geleden, lag dit nog anders.

Historisch zijn de publicaties van Dirk Gouma over de pancreaschirurgie.

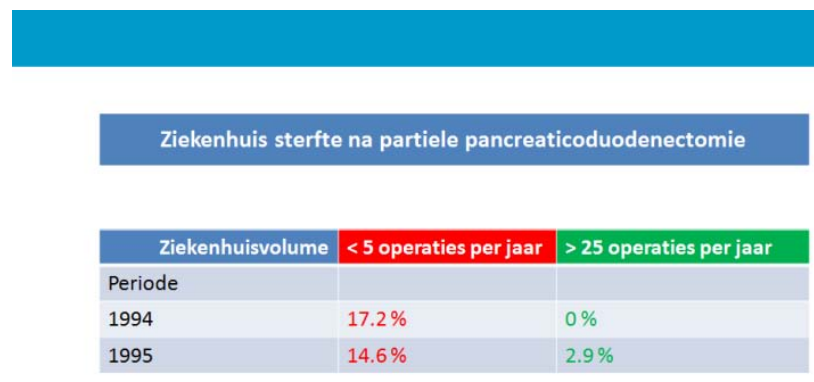

Ziekenhuiservaring en ziekenhuissterfte na partiële pancreaticoduodenectomie in Nederland

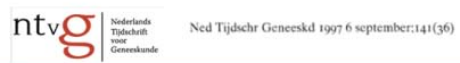

Hij beschreef het gunstige effect van een hoog ziekenhuisvolume: dit betekende een lagere ziekenhuissterfte na deze operatie.

Hoe duidelijk ook zijn getallen, dit had nog niet geleid tot concentratie van zorg.

In de regio Leiden-Den Haag-Delft, verenigden in die tijd de oncologisch en maagdarm chirurgen zich tot een zogeheten chirurgisch oncologisch netwerk met als doel om als eerste regio in het land echt werk te maken van concentratie van zeldzame grote operaties. Dit is vooral de verdienste van Bas de 
Vries, destijds chirurg in het Westeinde ziekenhuis (nu Medisch Centrum Haaglanden), en Willem Hans Steup, chirurg in het Leyenburg (nu Haga) ziekenhuis. Zij waren de initiatoren. Ik heb geholpen bij het vormgeven. In 1999 spraken wij af gedurende enige jaren de resultaten van de laagvolume hoogrisico ingrepen bij te houden en deze te vergelijken met de resultaten van de 10 jaar daarvoor. Deze resultaten zouden bepalen in welke ziekenhuizen voortaan nog welke operaties zouden plaatsvinden.

De gevolgen voor de slokdarmoperaties ziet u op deze dia.

\section{Concentratie van slokdarm chirurgie}

Regio Den Haag - Leiden - Delft

\begin{tabular}{|l|l|l|l|}
\hline Periode & $\begin{array}{l}\text { Aantal } \\
\text { ziekenhuizen }\end{array}$ & $\begin{array}{l}\text { Aantal resecties per } \\
\text { ziekenhuis per jaar }\end{array}$ & $\begin{array}{l}\text { Mortaliteit in } \\
\text { regio }\end{array}$ \\
\hline $1900-1999$ & 9 & $1.5-6.5$ & $12 \%$ \\
\hline $2000-2003$ & 8 & $1-14$ & $6 \%$ \\
\hline
\end{tabular}

Alleen al de aandacht voor deze chirurgie, zonder echte afname van het aantal ziekenhuizen dat de ingreep deed leidde tot een halvering van de mortaliteit: van $12 \%$ in de voorbije 10 jaar naar $6 \%$.

Wanneer we ook kijken naar de invloed van het volume aan operaties

\section{Concentratie van slokdarm chirurgie}

Regio Den Haag - Leiden - Delft

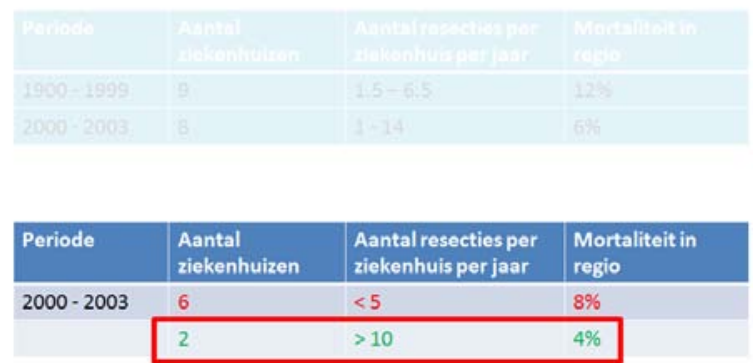

is het effect nog groter. In de 2 ziekenhuizen waar inmiddels meer dan tien operaties per jaar gebeurden, bleek de mortaliteit 4\%. De slokdarmoperaties werden vanaf toen in deze twee ziekenhuizen geconcentreerd.

Tegelijkertijd mocht ik met Jan van Lanschot het chirurgische deel van de eerste landelijke richtlijn over slokdarmchirurgie schrijven. Geholpen door kennis uit de literatuur en uit de Leids-Haags- 
Delftse samenwerking werd bepaald dat in een instituut minimaal 10 slokdarmresecties per jaar moesten plaatsvinden.

Deze feiten markeerden het begin van het tijdperk van kwaliteitsnormen en concentratie van zorg.

De Nederlandse Vereniging voor Gastrolntestinale Chirurgie (de NVGIC) en de Nederlandse Vereniging voor Chirurgische Oncologie (de NVCO) hebben normen opgesteld voor het hele terrein van de maagdarm- en oncologische chirurgie.

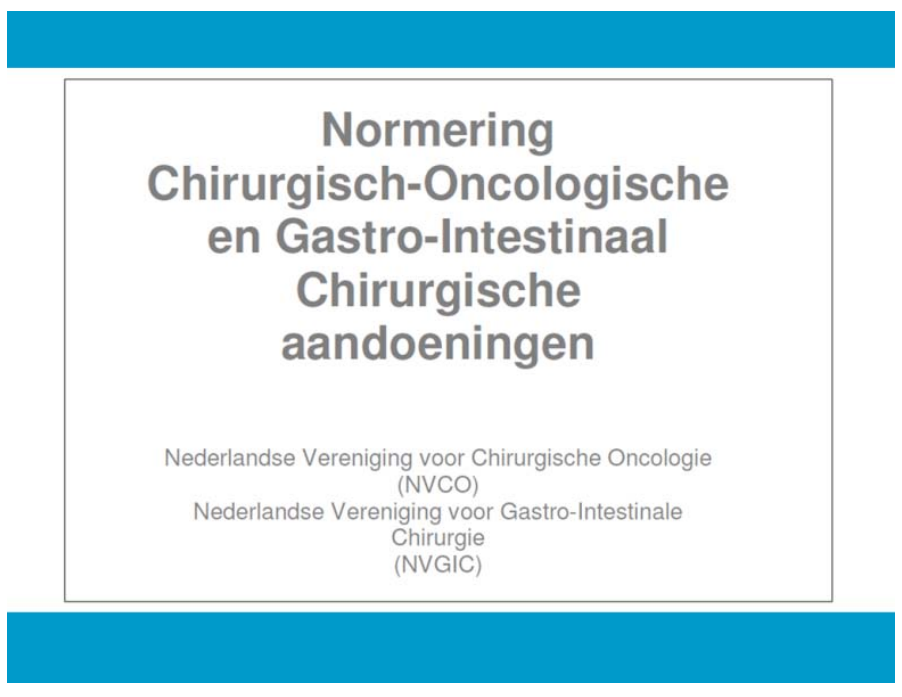

Dit document bevat eisen waaraan een ziekenhuis moet voldoen om bepaalde vormen van deze chirurgie te mogen uitvoeren.

De Nederlandse Vereniging voor Heelkunde heeft vervolgens een commissie normering en certificering ingesteld voor alle delen van de heelkunde.

Jean Klinkenbijl en ik, als toenmalige voorzitters van de NVCO en de NVGIC, hebben het eerste traject begeleid en mogen nu genoemde commissie voorzitten. Deze trajecten gingen niet zonder slag of stoot, maar opvallend is dat het land er toch van doordrongen was dat de tijd rijp was voor dit soort kwaliteitseisen. Alle subverenigingen en het bureau van de Nederlandse Vereniging voor Heelkunde hebben deze initiatieven tot speerpunt gemaakt.

Deze normen zijn niet vrijblijvend en ook niet zonder consequenties. De Inspectie voor de Volksgezondheid ziet toe op naleving door de ziekenhuizen. De ziektekostenverzekeraars sluiten geen contracten met instellingen die niet aan de eisen voldoen. Dit heeft ertoe geleid dat ziekenhuizen en zorgverleners keuzes hebben moeten maken. Er is concentratie van zorg opgetreden waardoor niet meer in alle ziekenhuizen alle zorg verleend wordt.

Een tweede traject dat de Nederlandse Vereniging voor Heelkunde is gestart is certificering van de individuele chirurg. 


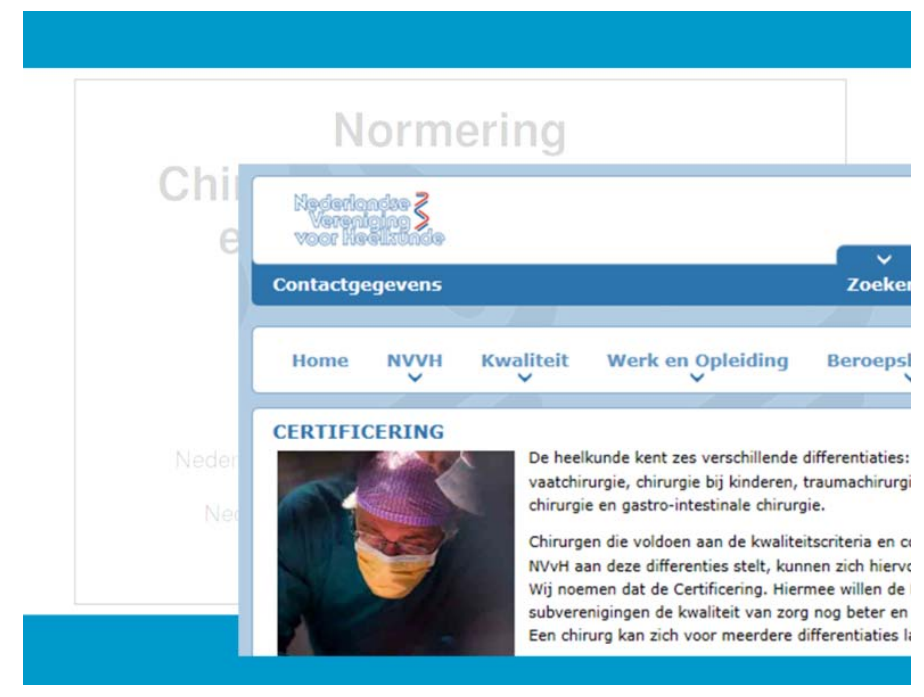

ledere specialist in Nederland heeft een zgn. BIG registratie als arts en een registratie als specialist. In aanvulling hierop verleent de $\mathrm{NVvH}$ registratie als gespecialiseerd chirurg zoals bijvoorbeeld ongevalschirurg, vaatchirurg, of maagdarmchirurg. Eisen voor deze registratie betreffen nascholing, aantallen verrichte operaties per jaar en werkkring van de specialist. Zonder dit brevet kan de chirurg dat deel van de heelkunde niet uitoefenen.

Dames en heren, in nog geen 10 jaar tijd heeft de heelkunde een enorme verandering ondergaan. Voor de buitenwereld is de zorg transparant geworden. Als er certificaten van normering en certificering aanwezig zijn weet de patient dat hij of zij voor deze zorg bij het juiste instituut en de juiste specialist is aangekomen.

Maar ook voor de professional is het leven enorm veranderd. Vrijwel geen specialist of ziekenhuis voert nog exact dezelfde zorg uit als 10 jaar geleden. En de attitude van de specialist is blijvend veranderd. Keuzes maken, toetsbaar opstellen, kennen van eigen grenzen en maatschappelijke verantwoordelijkheid hoorden altijd al bij het vak van arts, maar zijn veel hogere prioriteiten geworden. Dit betekent dat wij ook de aankomend specialist meer dan ooit hierin zullen moeten scholen. Daarover later meer.

Een korte uitstap ter verluchtiging. Het is goed onszelf ook op de hak te nemen. De heelkunde is niet de enige groep die normen opstelt. Wij lopen wel voorop maar staan niet alleen.

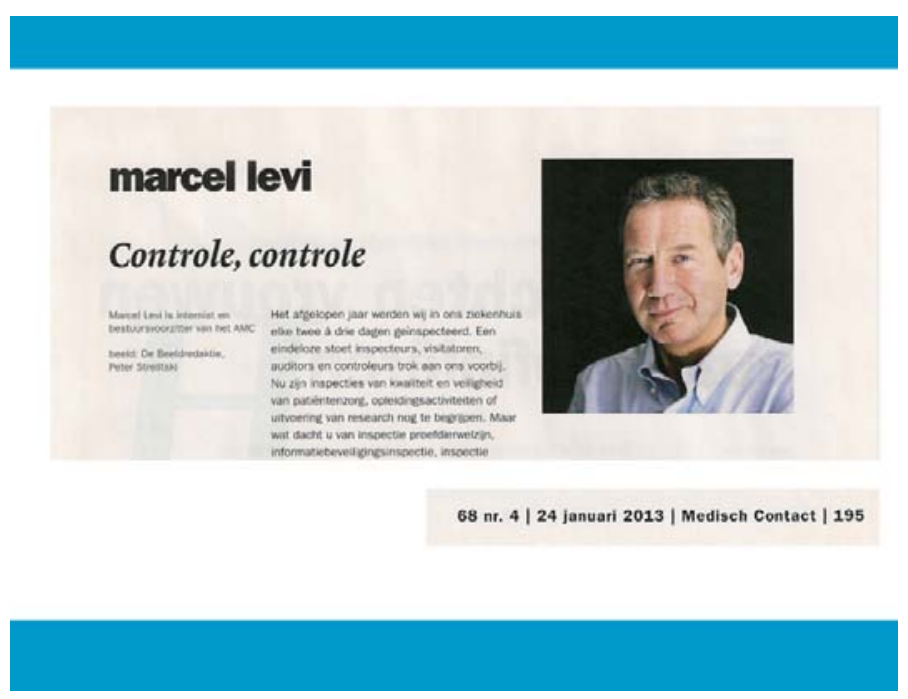


De voorzitter van de Raad van Bestuur van het Academisch Medisch Centrum in Amsterdam, Marcel Levi, geeft in dit commentaar aan dat zijn instelling iedere 2 a 3 dagen geïnspecteerd wordt, in het kader van een of andere norm. Het blijkt aan de orde van de dag dat richtlijnen elkaar tegenspreken. Toegankelijkheid is in strijd met informatiebeveiliging, brandweerregels zijn in strijd met die van de kernenergie controleur etc. Het is een noodkreet die ons oproept om normen af te stemmen, de regels niet te dol te maken, en ons gezond verstand te blijven gebruiken en soms keuzes te maken: niet alles kan.

Nu naar een tweede grote ontwikkeling die de maagdarm chirurgie de laatste jaren heeft doorgemaakt: de kleine operaties.

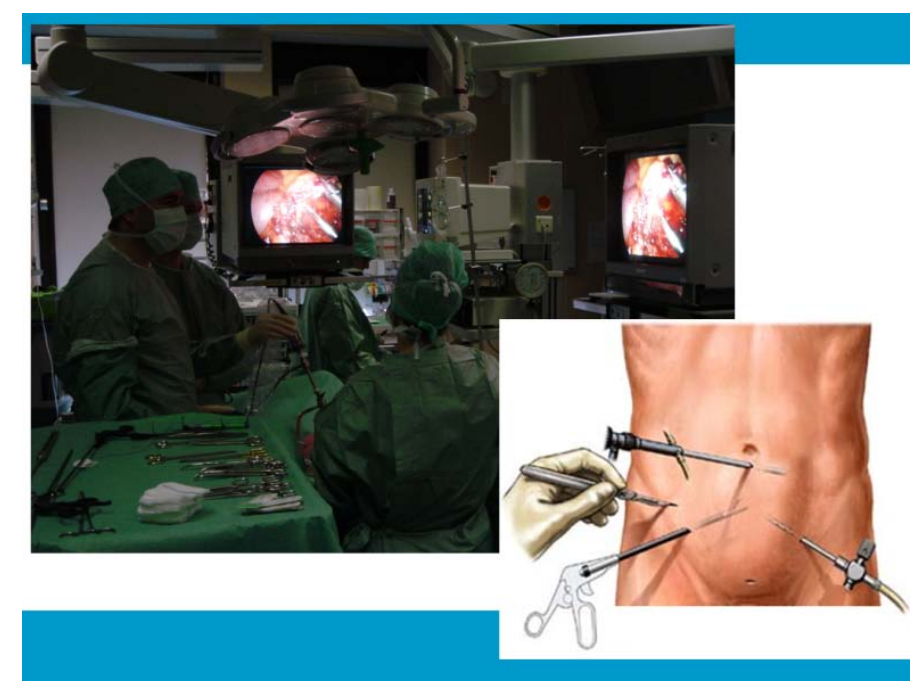

Daarmee bedoel ik operaties via kleine sneetjes: de minimaal invasieve chirurgie, ook wel genoemd de kijkoperatie of laparoscopische chirurgie.

Deze vorm van chirurgie heeft mijn carriere sterk beïnvloed. Mijn generatie heeft de opkomst ervan meegemaakt en zowel open als minimaal invasieve chirurgie van leermeesters mogen afkijken. Daarna ben ik betrokken geweest bij onderwijs in deze techniek en het optimaliseren van de uitvoering. Graag deel ik een aantal wetenswaardigheden met $u$ en blik vooruit naar een boeiende toekomst.

Mijn eerste kennismaking met de kijkoperatie was in 1991 in mijn huidige ziekenhuis. Peter Go en Dirk Gouma waren druk doende met de voorbereidingen voor de eerste laparoscopische cholecystectomie (galblaasverwijdering dmv een kijkoperatie) in het academisch ziekenhuis Maastricht. Inmiddels waren Jack Jakimovicz en Willem van Erp hen al voorgegaan: in Eindhoven was deze operatie voor het eerst in Nederland uitgevoerd. In mijn vervolgopleiding in Rotterdam trof ik naast mijn eerder al genoemde leermeesters ook Jaap Bonjer. Van hem en met hem heb ik veel op het vlak van de endoscopische chirurgie geleerd.

De aftrap van de kijkoperaties in Maastricht werd omgeven door spanning en media aandacht. Terecht: het was een geheel nieuwe operatietechniek, met de belofte dat deze revolutionair kon zijn, maar met direct ook al duidelijk een keerzijde.

\section{Welke beloftes had de minimaal invasieve chirurgie?}

Beloftes op korte termijn waren een beter cosmetisch resultaat, minder pijn voor de patient en een sneller herstel. Op de langere termijn minder kans op een littekenbreuk en, door subtielere omgang 
met de buikorganen, minder kans op verklevingen. Op deze gebieden heeft de kijkoperatie haar beloftes waargemaakt.

\section{Is er ook een keerzijde?}

Ja, van meet af aan was ook duidelijk dat er nadelen aan de nieuwe techniek kleefden. Ten eerste betrof het een geheel nieuwe operatietechniek.

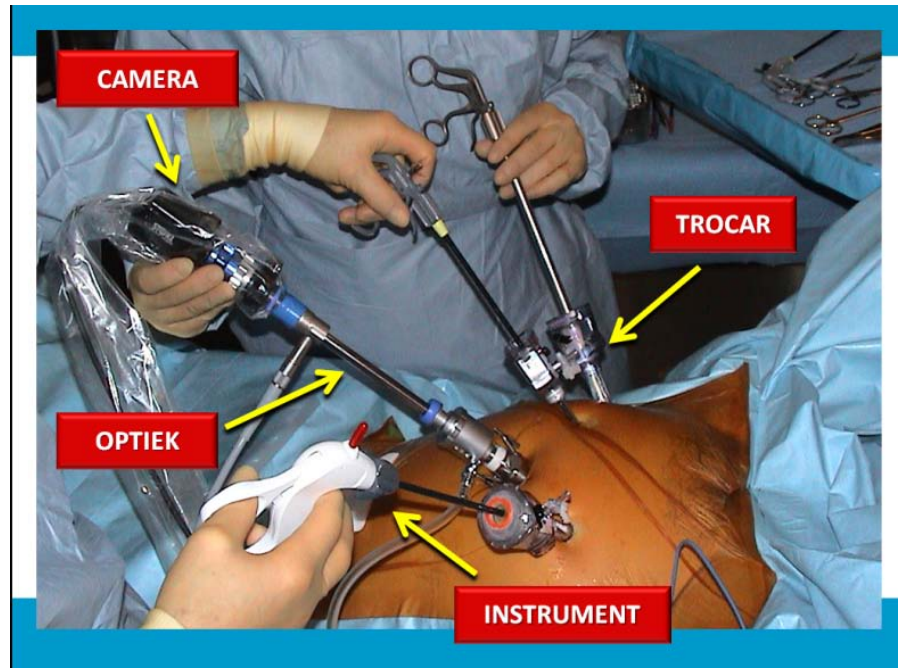

In plaats van met zijn eigen ogen kijkt een chirurg bij de kijkoperatie met een kijker, het optiek en een camera. Instrumenten worden door houders, trocars, in de buikwand gestoken. De instrumenten scharnieren om het insteekpunt in de buik, waardoor een beweging van het instrument uitwendig in een bepaalde richting een tegengestelde beweging inwendig veroorzaakt. Het beeld van de camera wordt weergegeven op een beeldscherm. Dit scherm geeft een 2D beeld van de 3D werkelijkheid. Dit alles geeft misoriëntatie bij de chirurg en een veranderde ooghand coördinatie.

Tot slot is de chirurg meer dan ooit tevoren afhankelijk geworden van apparatuur.

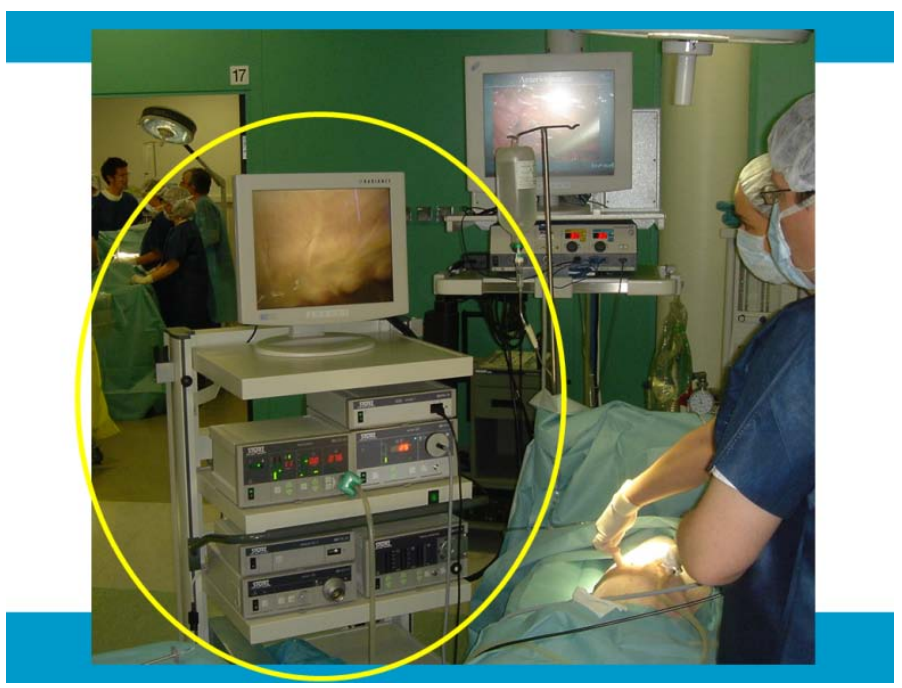

Alle onderdelen kunnen falen of suboptimaal presteren.

\section{Complicaties}


Deze nadelen hebben ertoe geleid dat zich nieuwe complicaties voordeden of al bekende complicaties vaker optraden dan we gewend waren, zoals darm- bloedvat- of galwegletsel.

\section{Kwaliteitszorg, initiatief beroepsgroep, Inspectie}

Nog vrij recent, in 2007, publiceerde de Inspectie voor de Volksgezondheid een kritisch rapport: "Risico's van minimaal invasieve chirurgie onderschat".

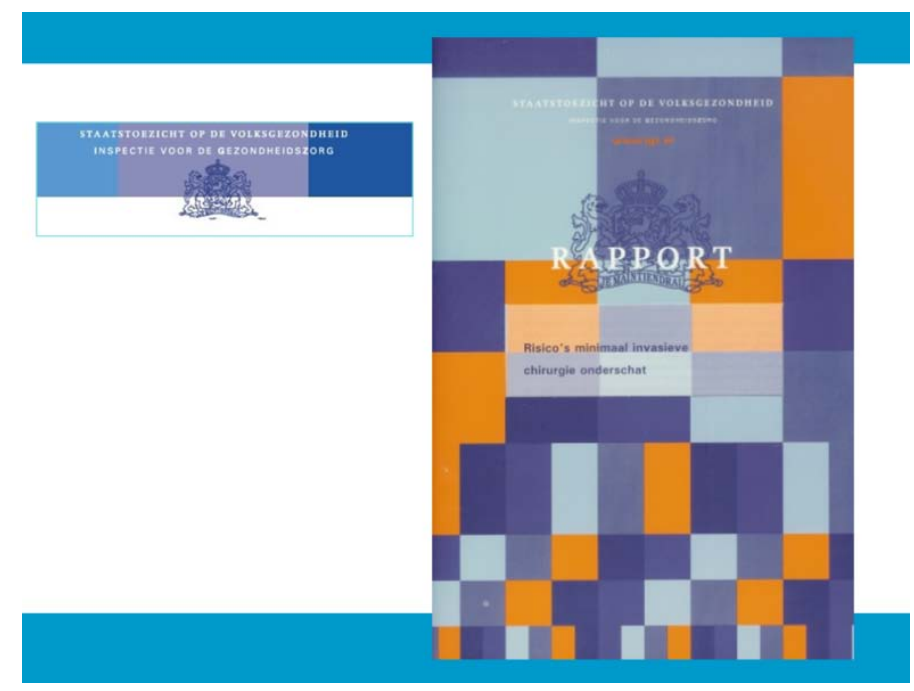

Zij stelde dat de veiligheid en kwaliteit onvoldoende waren gegarandeerd en training, protocollering en toezicht beter moesten.

Was het dan zo slecht geregeld? Ik denk het niet. Goed wetenschappelijk onderzoek had de voor- en nadelen in kaart gebracht, leercurves beschreven en trainingen werden gegeven. Maar vergeet niet wat ik eerder zei: wij leven in een tijd van transparantie en kwaliteit. Goed is niet goed genoeg.

Zo'n rapport is even slikken, maar moet vooral gezien worden als een steun voor verder wetenschappelijk onderzoek, voor kwaliteitszorg en voor training op het gebied van endoscopische chirurgie.

Laten we deze onderwerpen eens bekijken.

\section{Wetenschappelijk onderzoek}

Ik ben betrokken bij de MISIT onderzoeksgroep van de faculteit werktuigbouwkunde van de TUDelft. MISIT staat voor Minimally Invasive Surgery and Interventional Techniques. Deze groep stond aanvankelijk onder de bezielende leiding van wijlen Henk Stassen - geen familie - tegenwoordig van Jenny Dankelman. Artsen en ingenieurs werken samen aan praktische oplossingen voor klinische problemen. Paul Breedveld en Mark Wentink deden onderzoek naar de lastige ooghandcoordinatie. Hun inzicht is inmiddels standaard kost van introductiecursussen in de minimaal invasieve chirurgie. Belangrijk was de dag dat Mark binnenstapte met een omgebouwde muis en bijpassend computerprogramma 


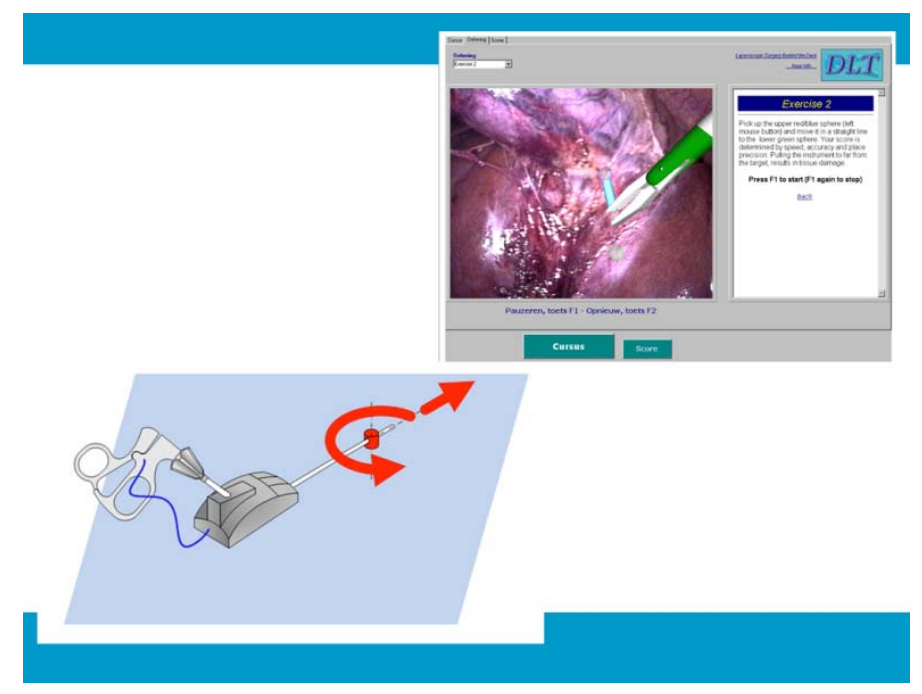

waarmee hij endoscopische bewegingen kon simuleren. Hij vond dit wel een handig modelletje om het probleem van de ooghandcoordinatie begrijpelijk aan de buitenwereld uit te leggen. Dit was een understatement. Zijn model is inmiddels uitgewerkt tot een Virtual Reality simulator van Nederlandse bodem: de Simendo.

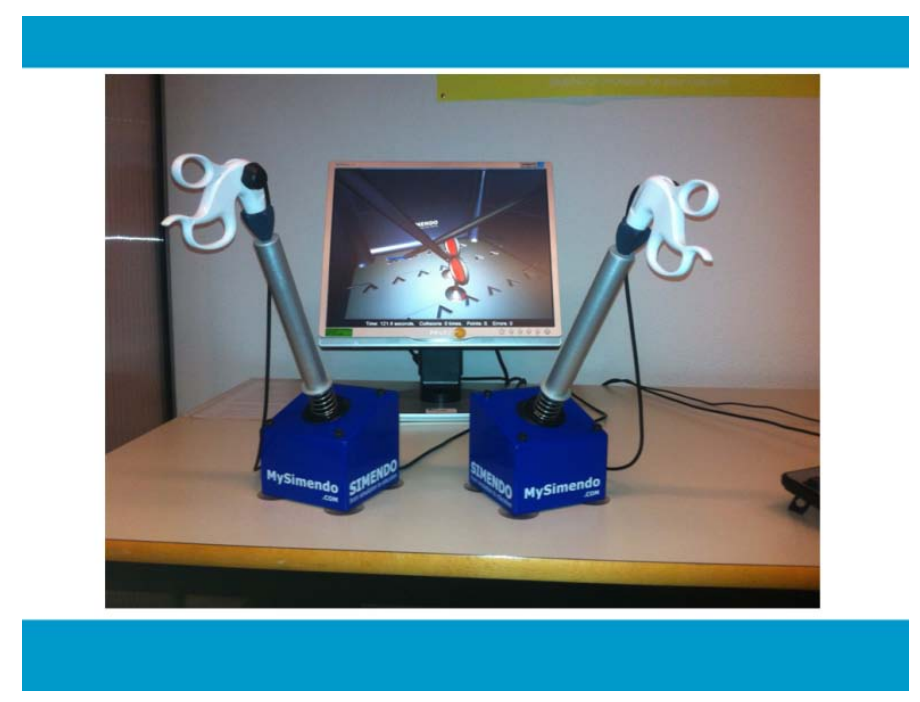

Zo'n VR simulator is een belangrijk hulpmiddel bij training in de endoscopische chirurgie. Wat is het precies en wat kunnen we ermee?

\section{Wat is een VR simulator?}

Een VR simulator bootst de handelingen na die een chirurg tijdens een kijkoperatie uit moet voeren. De handvatten en de bewegingen zijn net als in het echt. De patient is vervangen door een kleine box en het operatieterrein wordt gesimuleerd door een digitaal beeld. In dit nabootsen is een VR simulator overigens niet uniek. Simpeler is de zgn boxtrainer. 


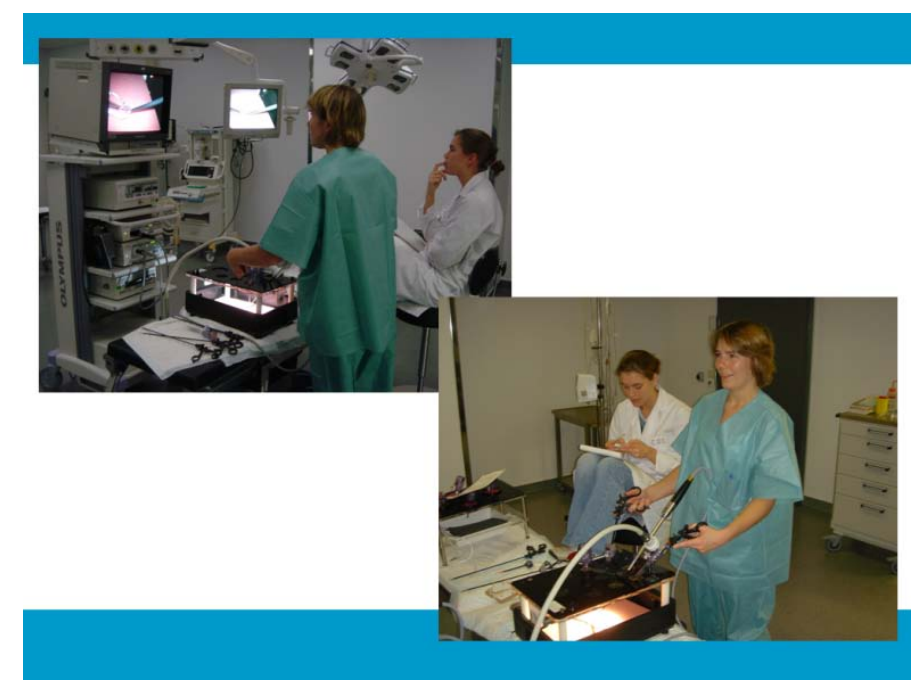

Deze simuleert hetzelfde maar maakt gebruik van gewone laparoscopische apparatuur. Het voordeel van de VR trainer is dat zijn digitale omgeving meer aanspreekt maar ook meting van alle prestaties bijhoudt. De ouderwetse box vraagt om een ouderwetse opleider die met aantekenboek in de hand de score volgt.

\section{Wat kan een VR simulator?}

Emiel Verdaasdonk, inmiddels bijna chirurg, heeft ons geholpen om de precieze waarde van een dergelijk apparaat vast te stellen. Hij heeft aangetoond dat de simulator inderdaad door gebruikers gewaardeerd wordt en dat oefening de endoscopische ooghandcoordinatie bevordert. Maar let op, het blijven trainers van basale vaardigheden. Alleen motoire handelingen worden geoefend.

\section{Hoe leren wij aankomend chirurgen de endoscopische chirurgie? Hoe ziet een gebalanceerd trainingscurriculum er uit?}

In mijn eigen opleidingstijd heb ik aan een van de eerste skillscursussen mogen deelnemen. Deze vond plaats op het varken. Het is indrukwekkend om als aankomend chirurg met echte instrumenten en apparatuur op een levend wezen een echte operatie te mogen uitvoeren. Dergelijke trainingscentra worden nog steeds veel gebruikt. Ook het MaastrichtUMC heeft er een.

Het trainingcurriculum van vandaag is genuanceerder. Andere trainingsmogelijkheden, de toenemende bewustwording van de kwetsbaarheid van proefdieren en onderwijskundig inzicht hebben geleid tot een gebalanceerde trainingsopzet. In onze opleidingsregio Limburg nu, maar dat was niet anders in mijn tijd in de Rotterdams-Delftse regio, bestaat een stapsgewijze scholing. De cursist bestudeert studiestof, legt een kennistoets af en doet hands-on training op de box en de VR simulator. 


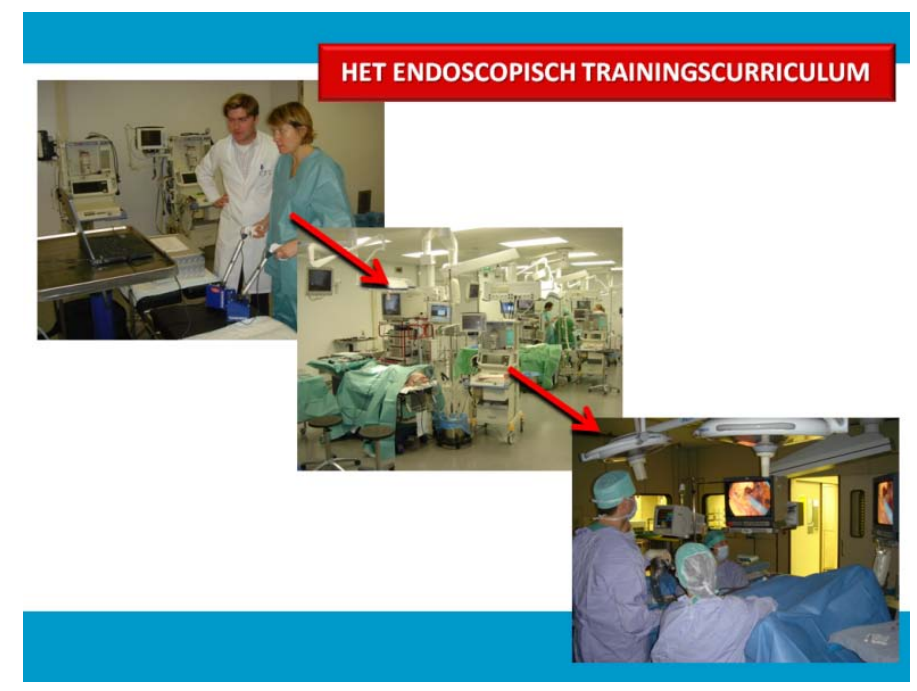

Daarna volgt een cholecystectomie op een losse varkenslever gevolgd door een aantal operaties op het varken. Pas hierna mag de chirurg in opleiding de eerste stappen van de operatie op een patient verrichten, strak gecoached door een volleerd chirurg.

\section{Hoe gaat deze training verder in de opleiding?}

Sinds 2006 worden landelijk gevorderde cursussen op het gebied van endoscopische chirurgie gegeven. Met zo'n 40 cursisten en 8 man faculty per keer bereiken we een hoog rendement en een zeer interaktief leerklimaat. Jeroen Meijerink en Erik Totte hebben deze cursussen ontworpen, met een solide organisatie: het OpleidingsCollege Endoscopische Heelkunde.

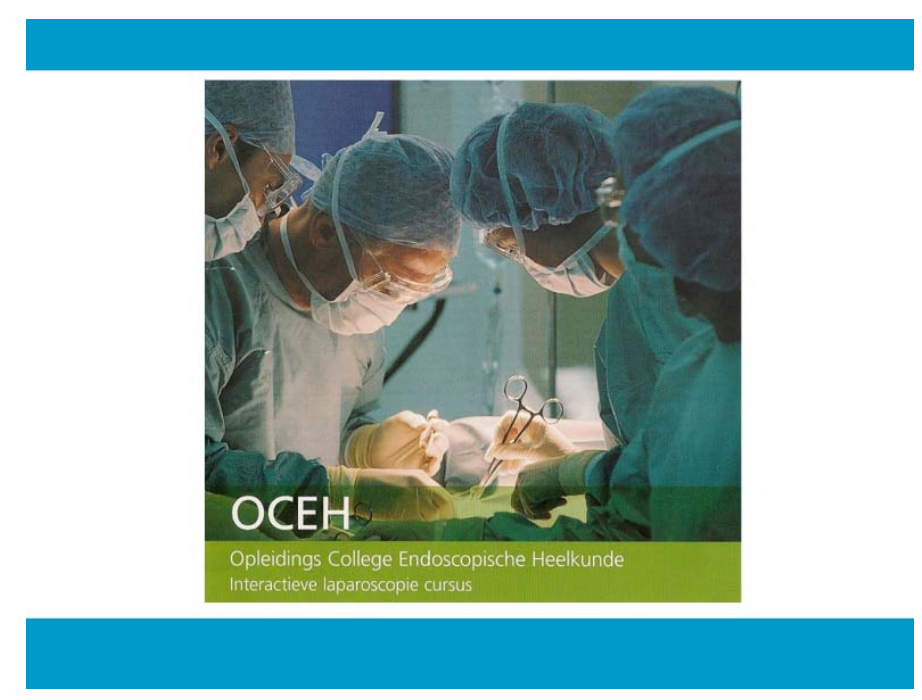

Met plezier maak ik hier deel van uit. Zo is een opleidingslang curriculum ontstaan met de basiscursus als instap en 3 OCEH cursussen in de jaren erna.

Er is hier enige zorg over morgen. Hoe mooi en nuttig deze opzet ook is, in tijden van crisis staan deze dure cursussen onder druk. Aan industrie en de Nederlandse Vereniging voor Heelkunde en Gastrointestinale chirurgie moeilijke keuzes: wat kan er nog en wie betaalt?

Graag bespreek ik nog een risico maar ook een handvat voor verbetering van de endoscopische chirurgie: de omgang met apparatuur. Een van onze onderzoeksprojecten aan de TUDelft toonde aan dat in $87 \%$ van de procedures er onvolkomenheden in omgang met de apparatuur optraden. Een 
checklist werd ontworpen, waarmee het aantal incidenten met de helft werd gereduceerd. $U$ zult denken, deze checklist is dus nuttig en breed in gebruik. Dat blijkt niet zo.

Bij een inventarisatie kort geleden bleek maar de helft van de Nederlandse ziekenhuizen een dergelijke lijst te gebruiken, en dan vaak nog in onvolledige vorm.

Hoe jammer dit ook is, toch een opmerking ter relativering.

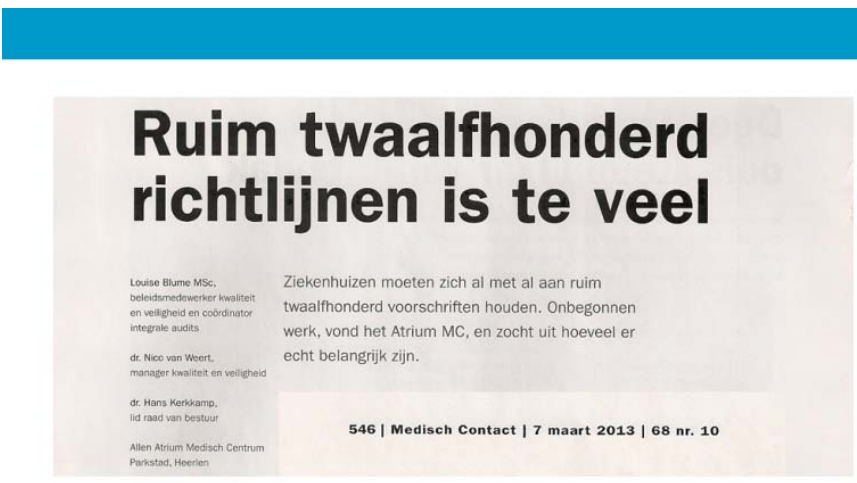

In een recent commentaar in het Medisch Contact schreven managers van het Atrium Medisch Centrum in Heerlen dat een gezondheidszorg instelling anno nu zich te houden heeft aan ruim 1200 wetten, regels en normen. Het is duidelijk: in het moderne woud aan regelgeving en checklists zullen we keuzes moeten maken.

Een keuze is om door adequate training het gebruik van bepaalde checklists overbodig te maken. Met de makers van de Simendo hebben we twee web-based trainingsmodules voor omgang met endoscopische apparatuur ontworpen.

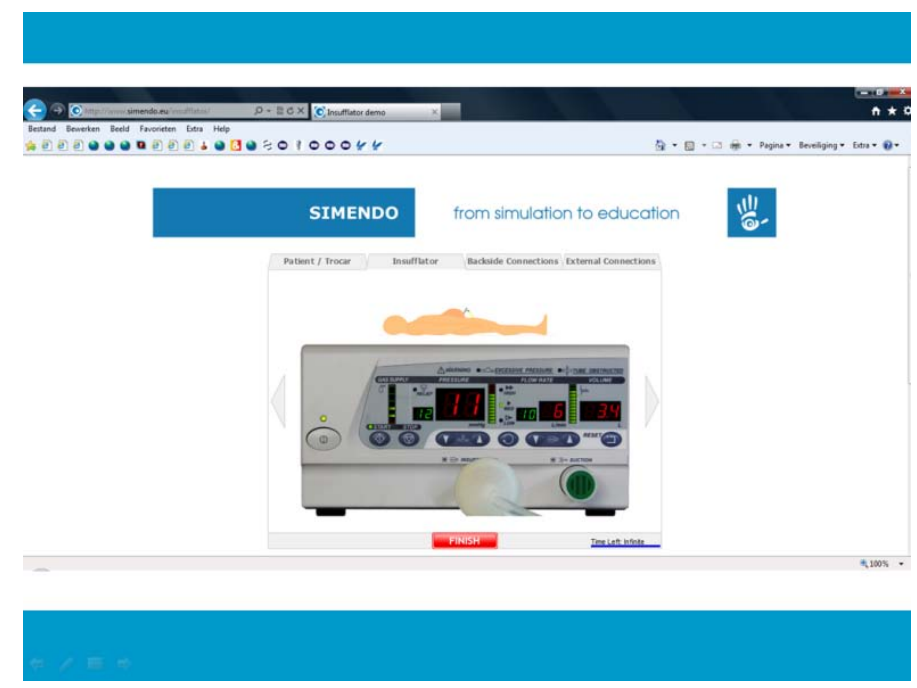

In het praktische deel kan de cursist webbased het apparaat bedienen dat geheel waarheidgetrouw is nagebootst. Validatie onderzoek toont aan dat de trainingsmodule leidt tot een betere bediening van het apparaat. Dit soort training kan de kans op fouten verminderen en laat de cursist de vrijheid op een zelf gekozen plaats en moment te trainen. 
Heel boeiend is ook nieuw onderzoek op het gebied van beeldvorming.

Ik wil twee ontwikkelingen met $u$ bespreken: spectraal analyse en near infrared fluorescentie imaging.

Deze technieken maken gebruik van andere golflengten dan die van het zichtbare licht en kunnen weefsel op een andere wijze typeren dan wij puur met onze ogen kunnen.

Voor het eerst zag ik een resultaat hiervan toen Fokko Wieringa van TNO beelden toonde van verschillende afbeelding van weefsel bij verschillende golflengten.

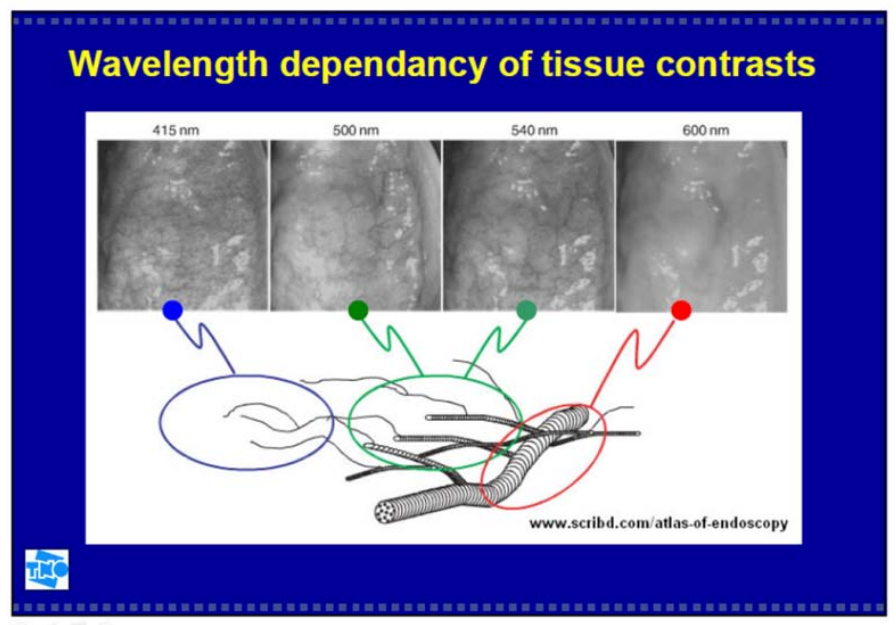

Verschillende golflengten hebben een andere diepte penetratie. Maar ook verschillende reflectie waarbij aard van het weefsel en zuurstofspanning een rol spelen. Op deze wijze bleek het mogelijk om slagaders en aders op de buitenzijde van het hart, onder een laagje vetweefsel verborgen, beter af te beelden dan met zichtbaar licht. Zou het mogelijk zijn om structuren die voor ons als gastrointestinaal chirurgen van groot belang zijn, bloedvaten, lymfklieren, zenuwen en urineleider, beter en sneller en zelfs onder een laag vetweefsel af te beelden? Stelt u zich voor wat dit zou betekenen voor veiligheid en opleiding.

In een groot, zogenaamd shared research, project met TNO en andere partners is het inmiddels gelukt om van de genoemde typen weefsel het specifieke spectrum op tal van golflengten te bepalen.

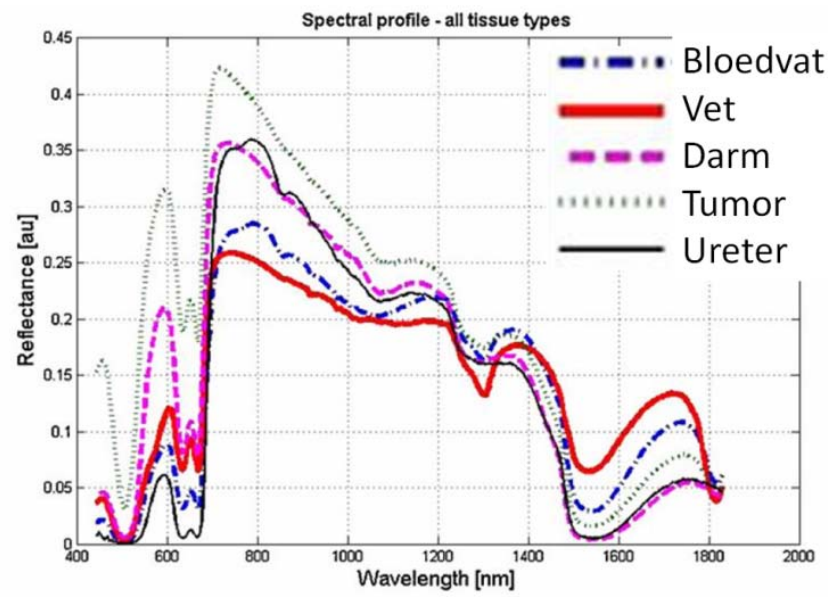

Deze grafiek staat nog ver af van voor de chirurg begrijpelijke beelden, maar een eerste stap is gezet. 
Begrijpelijke beelden levert al wel Near Infrared Fluorescentie Imaging op. Door golflengten net buiten het zichtbare licht te combineren met een fluoriscerende kleurstof kunnen wij bijvoorbeeld de galwegen afbeelden.
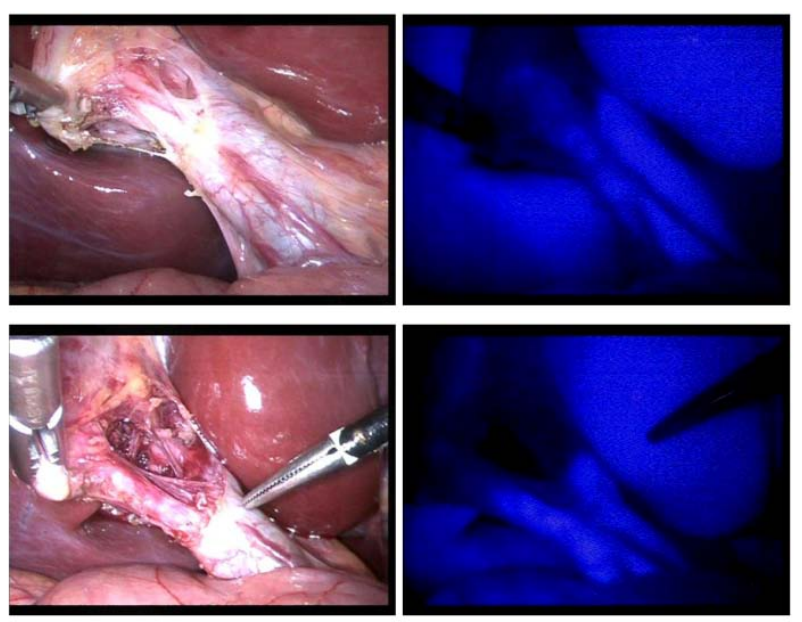

Deze komen door deze techniek, rechts op de dia, eerder in beeld dan met de gewone camera en licht, links te zien. Ook door dergelijke betere anatomische imaging zal het in de toekomst mogelijk worden om veiliger te opereren.

\section{OPLEIDING}

Het tweede deel van deze rede gaat specifiek over opleiding en onderwijs.

Ik noemde al veranderingen in de zorg: normering en certificering; differentiatie en centralisatie; kwaliteit en transparantie. De moderne arts moet meer dan ooit tevoren keuzes maken, zijn eigen grenzen kennen en maatschappelijke verantwoordelijkheid nemen. De aankomend specialist zal hier dus ook meer dan ooit in geschoold moeten worden. Dit stelt nieuwe eisen aan de opleiding.

\section{Wat is er al veranderd aan de opleiding tot medisch specialist?}

In 2002 verscheen het rapport "De arts van straks" van de commissie van der Veen.

Opgeroepen werd om zowel de basisopleiding tot arts als de vervolgopleiding tot medisch specialist grondig te herzien.

2 jaar later werden met een nieuw kader besluit van de CCMS, het orgaan dat de opleiding tot medisch specialist regelt, voor het eerst de 7 Canmeds competenties in Nederland geintroduceerd. 


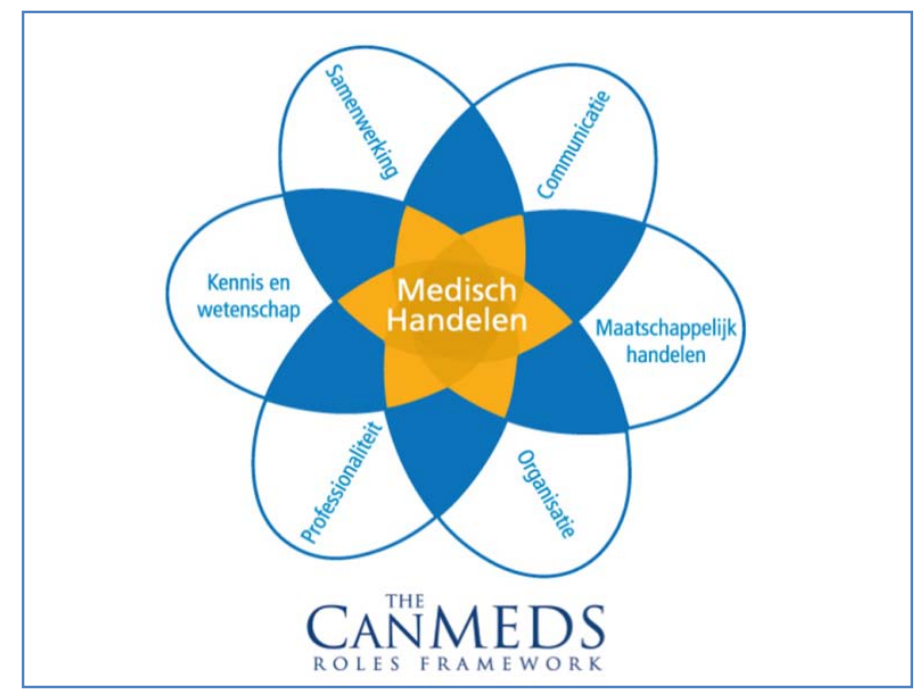

De moderne arts dienst op 7 vlakken competent te zijn: hij is medisch expert, wetenschapper, hij kan samenwerken en communiceren, is maatschappelijk betrokken (kan verantwoord omgaan met middelen), is organisator en is professioneel (kent zijn grenzen).

Vroeger stonden vooral medisch handelen en kennis en wetenschap centraal. Je moest je vak verstaan, je literatuur lezen en wetenschap dwong ontzag af. Aan het tekortschieten op andere terreinen werd wat minder belang gehecht.

Maar die andere terreinen zijn van groot belang geworden in het licht van de veranderende zorg. Centralisatie van zorg vraagt kennis van de eigen grenzen dus professionaliteit. Afstaan van zorg die een arts of ziekenhuis met veel plezier deed, maar elders beter gebeurt, gaat niet altijd van harte, maar prevaleert wanneer dit in het belang van de patient is.

Regionale afspraken over die centralisatie vereisen samenwerking en communicatie. Bijdragen aan kwaliteit en transparantie kan niet zonder maatschappelijk bewustzijn en professionaliteit.

Het opleiden in deze 5 algemene Canmeds competenties wordt landelijk zo belangrijk geacht

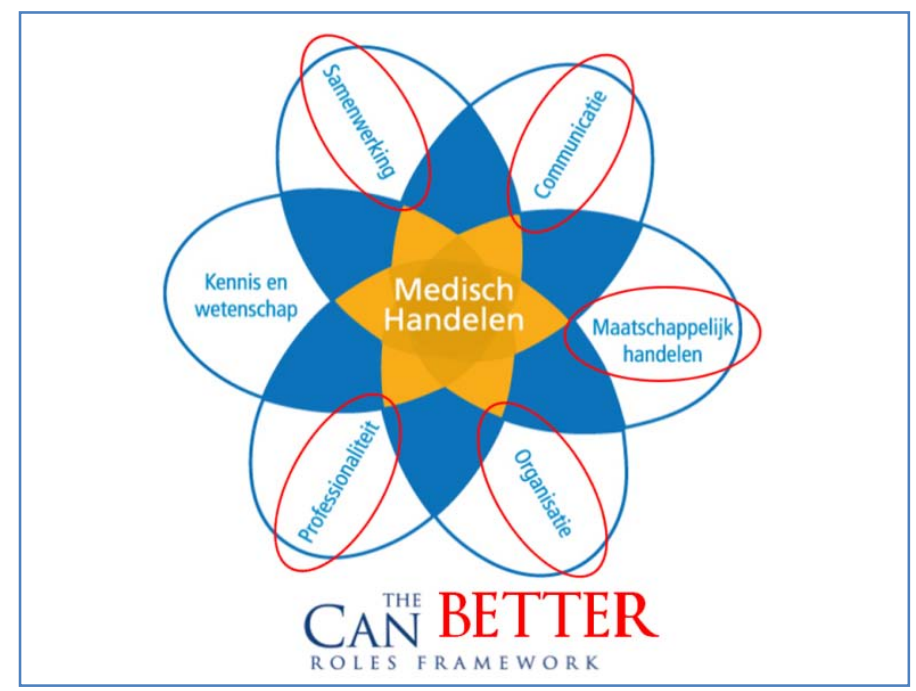

dat vanuit de KNMG een Canbetter werkgroep in het leven is geroepen speciaal om dit opleiden beter vorm te geven. 
Hoe houden wij in de gaten hoe de aios (dit is de arts-in-opleiding-tot-specialist) zich ontwikkelt en hoe helpen wij hem of haar daarbij?

Veel opereren en eenmaal per jaar een gesprek van een paar minuten met de opleider zoals vroeger volstaat niet meer.

De moderne opleiding bevat vele evaluatiemomenten.

\section{Feedback en evaluatie}

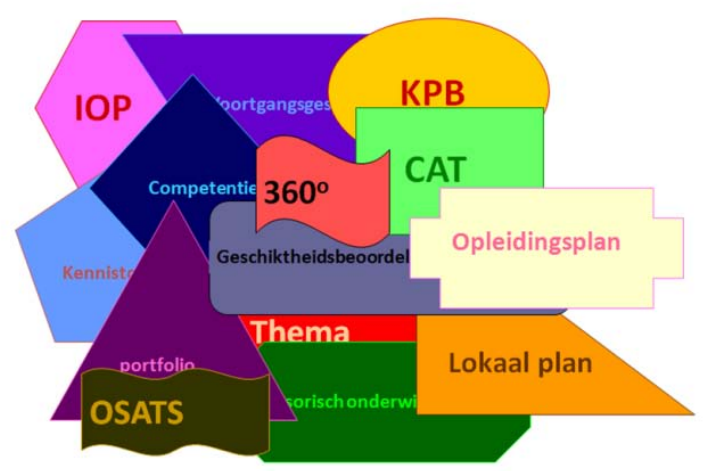

De assistent krijgt frequent feedback op sterke en op aandachtspunten. En de aios wordt gevraagd met de opleider een persoonlijk opleidingsplan op te stellen.

Maar ook de opleiders worden beoordeeld. Periodiek beoordelen de assistenten in opleiding het opleidingsklimaat van de afdeling maar ook de kwaliteiten van iedere individuele specialist als opleider.

Het nieuwe opleidingsplan van de Nederlandse Vereniging voor Heelkunde waar al deze nieuwigheden in staan dateert van 2006. Van hogerhand hebben we tot 2015 gekregen om dit vorm te geven. Zijn we er dan, is het werk dan af?

Neen, dat is het niet. Ik bespreek met $u$ de zaken die nu hoog op de agenda staan en aanpak vereisen.

\section{Differentiatie en de opleiding.}
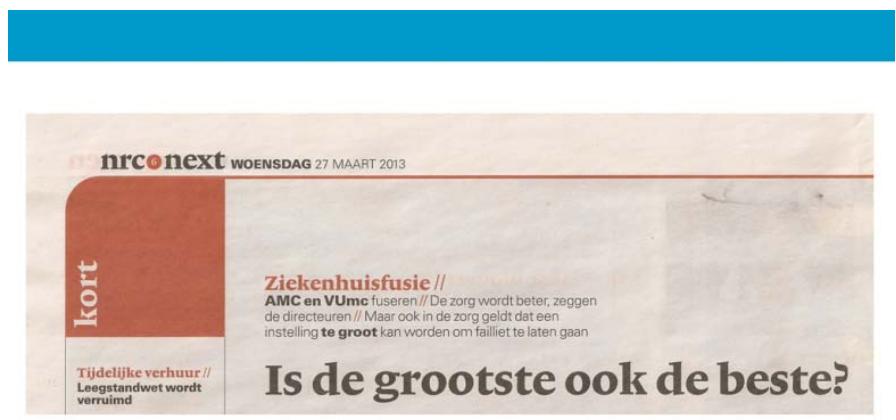
Dit recente artikel gaat over de op handen zijnde fusie van de Amsterdamse academies. De motivatie voor dergelijke fusies is vaak dezelfde: de norm moet gehaald worden. Door volume- en kwaliteitsnormen moet het ziekenhuis steeds meer volume leveren, dus groter worden, en de specialist moet zich steeds verder differentieren. Dit artikel zegt daarover: "De algemeen chirurg, bijvoorbeeld, bestaat nog amper - hij legt zich toe op een paar soorten operaties die hij vervolgens heel vaak uitvoert."

De Nederlandse Vereniging voor Heelkunde discussiert hoever we moeten gaan met die differentiatie. Nu bestaat de opleiding tot chirurg uit een algemeen deel van 4 jaar en een aansluitende differentiatiefase van 2 . Vraagt de maatschappij om 4 jaar differentieren? Dat betekent dat de algemene heelkunde als moeder specialisme zou kunnen verdwijnen. Wat maakt de heelkunde dan immers nog anders dan bijvoorbeeld de urologie of de plastische chirurgie, opleidingen die ook bestaan uit twee jaar vooropleiding algemene heelkunde en 4 jaar specialisatie? Daar is de heelkunde nog niet aan toe, zichzelf op te heffen. Voorlopig wordt waarschijnlijk gekozen voor een gedeeltelijk gedifferentieerd $4{ }^{\mathrm{e}}$ jaar, nog niet meer dan dat. Maar wij zullen in het belang van de aios, nauwlettend moeten volgen welke ontwikkelingen de maatschappij van ons vraagt.

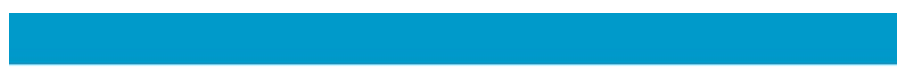

\section{Zorgconcentratie heeft} grote impact op aios

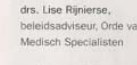

446 | Medisch Contact | 14 februari 2013 | 68 nr. 7

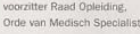

Dit onderwerp raakt aan het vorige. Veel ziekenhuizen zullen toch niet een omvang hebben dat zij alle zorg kunnen blijven leveren. En dit is een dynamisch proces, de inrichting van de zorg vandaag kan morgen weer anders zijn. Dit betekent dat de aios zijn voorkeursmogelijkheden voor zijn opleiding kan zien veranderen. Stages die bedacht waren kunnen misschien niet meer in de beoogde ziekenhuizen worden gelopen.

Hier komt het regionaal opleiden om de hoek. De regionale opleiders zullen samen de sterke punten van hun ziekenhuizen en de veranderingen goed in beeld moeten hebben, goed moeten etaleren en in overleg met de aios een gebalanceerde opleiding moeten uitstippelen.

Mag ik een zorg met u delen?

De aios. 


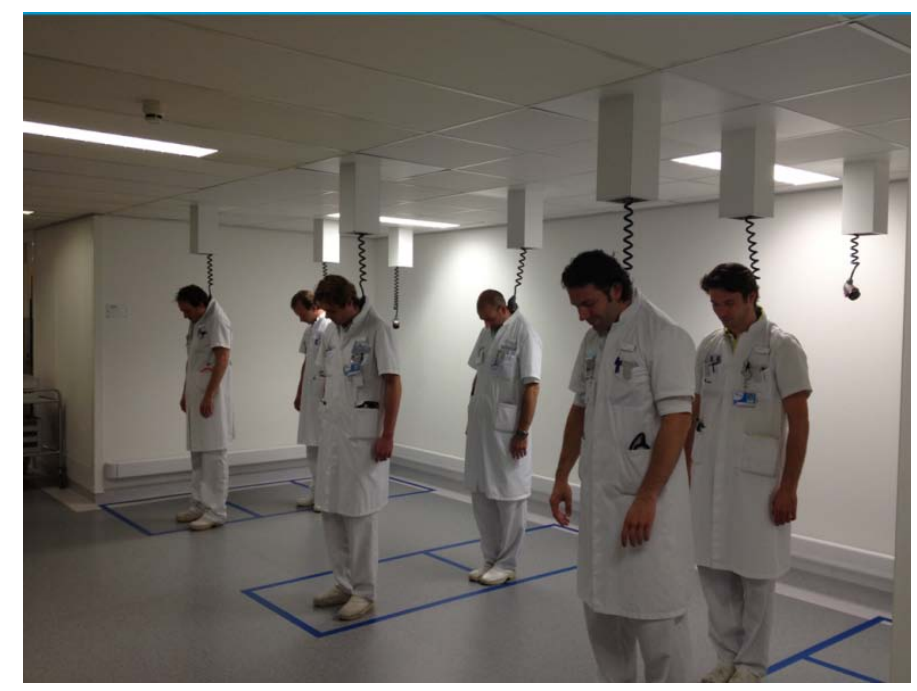

Is dit hun toekomst: het oplaadpunt voor aios? Wij stellen hoge eisen aan hen. En zij stellen hoge eisen aan zichzelf. In werk en privé.

Wij zullen als opleiders de aios moeten helpen inzichtelijk te maken waar hun sterke kanten en lacunes zitten. Het is ontwikkelingswerk: wij moeten de aios leren zichzelf te ontwikkelen en staande te houden. De aios als regisseur van zijn eigen opleiding.

\section{ONDERWIJS}

Tot slot dames en heren: het onderwijs. In de medische wereld wordt hieronder het onderwijs aan studenten verstaan: de studie geneeskunde, ook wel genoemd de basisopleiding.

\section{Een aantal vragen komt aan bod.}

Welke invloed moeten de ontwikkelingen in de specialistische vervolgopleiding hebben op de basisopleiding?

Maar ook: welke ontwikkelingen of expertise uit de basisopleiding kunnen wij goed gebruiken in de vervolgopleiding?

En: hoe werken we samen in de OOR, de opleidings- en onderwijsregio, om met elkaar maximaal rendement te halen.

En tot slot: hoe bieden wij samen, de basisopleiding en de vervolgopleidingen, nieuwe uitdagingen het hoofd?

Eerst een korte terugblik op het onderwijs aan onze faculteit. Maastricht is een jonge medische faculteit maar heeft een rijke en unieke historie. 


\section{GESCHIEDENIS}

Eerste hoogleraar geneeskunde Maastricht: Pelerin Harry Hillen

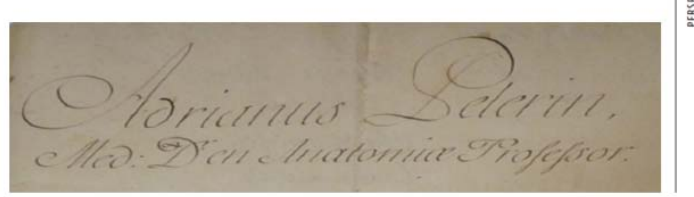

NESTUDSCHR GENESKK 2010:154:A1525

Adrianus Pelerin was de grondlegger van het geneeskundig onderwijs in Maastricht. Hij werd in 1738 benoemd tot eerste hoogleraar Geneeskunde aan de zogenaamde Illustre School in deze stad. Studenten woonden zijn lessen bij, waarin menselijke lichamen werden ontleed. Deze studenten stroomden vervolgens door naar een universitaire studie in het noorden van het land. Onze Illustre School was dus een bacheloropleiding avant la lettre.

Ruim twee eeuwen later, in 1973, legde een club van 7 founding fathers de basis voor onze huidige faculteit en academisch ziekenhuis. Het probleemgestuurd opleiden, afkomstig van de McMaster University in Canada, werd in Maastricht geintroduceerd. Een van de founding fathers was wijlen Ko Greep, chirurg.

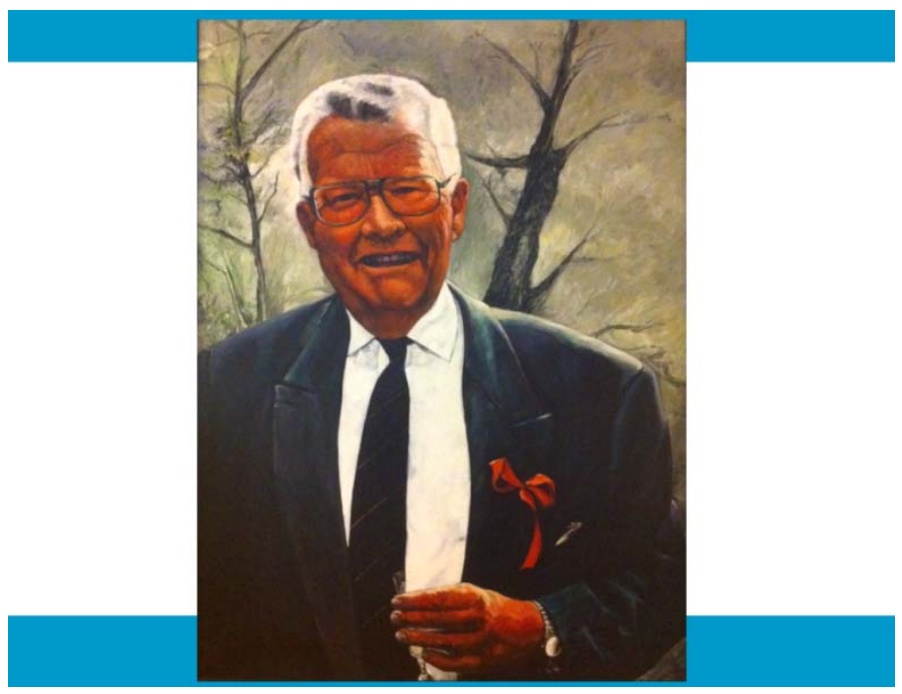

Greep was een groot man. Ooit geopereerd aan zijn blinde darm in het Bethel ziekenhuis in Delft, werd hij chirurg, bracht 3 jaar door in Boston, startte in ' 66 samen met Brummelkamp het Lukas ziekenhuis in Amsterdam, en stond aan de wieg van onze eigen faculteit en academisch ziekenhuis. Als bouwdirecteur heeft hij gezorgd voor het MUMC zoals het er nu staat: faculteit en ziekenhuis broederlijk naast elkaar, de start voor echte samenwerking.

Hij zei in zijn afscheidsrede in ' 92 dat hij werkte in een tijd dat "de bomen tot de hemel groeiden". Zijn assistenten profiteerden daar dankbaar van. ledere aios ging verplicht voor een jaar onderzoek naar Amerika, met vrouw en kinderen. Groeiden de bomen nog maar steeds zo hoog. 
Greep sprak ook in zijn afscheidsrede: "het komt misschien zover dat artsen leren opereren met behulp van een simulator zoals ook piloten dat doen". Hij heeft gelijk gekregen. Wekelijks worden onze assistenten getraind in het simulatiecentrum van ons ziekenhuis.

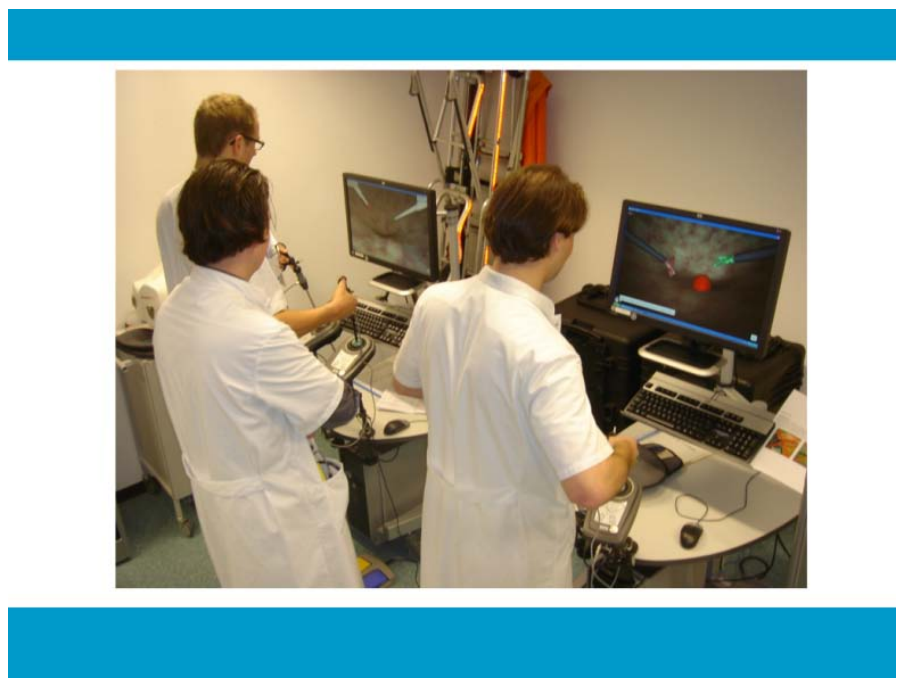

Terug naar het heden. Maastricht neemt het serieus met het onderwijs. Niet alleen ik heb een onderwijstaak in mijn leerstoel, dit geldt ook voor recent benoemde hoogleraren zoals Richard Koopmans, Gerard Bos, Mirjam oude Egbrink, Ton de Goeij en, kersvers, Ide Heijligers uit de periferie. We hebben een club om mooie dingen mee te doen.

\section{Welke taken liggen er op het gebied van onderwijs?}

Ten eerste afstemming van de basisopleiding en de specialistische vervolgopleidingen. Belangrijk aandachtspunt hierbij zijn de al genoemde overige competenties.

Gelukkig staan deze algemene Canmeds competenties ook hoog op de agenda van onze faculteit. De net genoemde hoogleraren Oude Egbrink en de Goeij, respectievelijk wetenschappelijk directeur van het onderwijsinstituut en opleidingsdirecteur geneeskunde, gaven in hun oraties op 19 oktober $\mathrm{jl}$ aan dat het hun ambitie is om onze studenten hierin op hoog niveau te scholen. De medische vervolgopleiders, zoals ik, zullen bijspringen om de studenten geneeskunde dit met de paplepel in te gieten: hoe jonger geleerd, hoe beter gedaan.

Ik ga nog een stapje verder. Ik heb nog niet onze ambitie met $\mathrm{u}$ gedeeld om het profiel doelmatigheid in te bedden in de medische vervolgopleiding. Los van het feit dat dit een hot item is in de moderne gezondheidszorg, heeft een arts al die eerder genoemde competenties nodig om doelmatig te kunnen werken. Opleiden in doelmatigheid betekent dan ook opleiden in die competenties. Ook maatschappen zijn zeer gebaat bij collega's met dit profiel. Voor een maatschap anno nu telt meer dan ooit organisatietalent en verstand van budgettering. Nu al zijn er aios heelkunde bij ons die op eigen initiatief aanvullende scholing volgen op het gebied van management, organisatie en doelmatigheid in de zorg. De specialistische opleiding schiet op dit punt nog tekort.

Onze ambitie is om zowel in de basisopleiding als in de vervolgopleiding dit profiel vorm te geven. En om aanvullende scholing bijvoorbeeld in de zin van minor- of masteropleidingen ook door eigen talent van de Univeristeit Maastricht te laten verzorgen.

\section{Welke expertise uit de basisopleiding kunnen wij goed gebruiken in de vervolgopleiding?}

Dit is met name onderwijskundige expertise. In de basisopleiding zit een schat aan kennis op dit terrein. Wij mogen ons in Maastricht gelukkig prijzen met de internationaal vermaarde vakgroep 
Onderwijsontwikkeling en -onderzoek en de School of Health Professions Education onder leiding van Cees van der Vleuten.

Het opleiden op de werkvloer, daarin zijn specialisten meester. Op ander vlak kunnen zij hulp gebruiken, bijvoorbeeld bij de moderne opleidingsplannen en in het zogenaamde discipline overstijgend onderwijs.

In die opleidingsplannen beschrijft ieder specialisme de inrichting van de moderne opleiding. Er zijn landelijke, regionale en lokale plannen. Onderwijskundigen helpen ons om daarin de juiste doelen voor ogen te houden en effectief op te leiden.

Discipline overstijgend onderwijs is de tweede plek voor onderwijskundige hulp. Dit onderwijs is bedoeld om jonge dokters extra te scholen in de zaken die op de dagelijkse werkvloer zo belangrijk zijn dat deze gericht aanvullend onderwijs verdienen: samenwerking, communicatie, maatschappelijk handelen. Cursussen hierin hebben titels als Het slecht-nieuws gesprek, Verbetermanagement, Patientveiligheid. Onderwijskundigen zijn in the lead bij de doordachte opzet van dergelijke cursus, artsen zorgen voor een inhoud die aansluit bij de praktijk.

\section{De samenwerking tussen de basisopleiding en de medisch specialistische vervolgopleiding lijkt} vanzelfsprekend maar is dit niet perse.
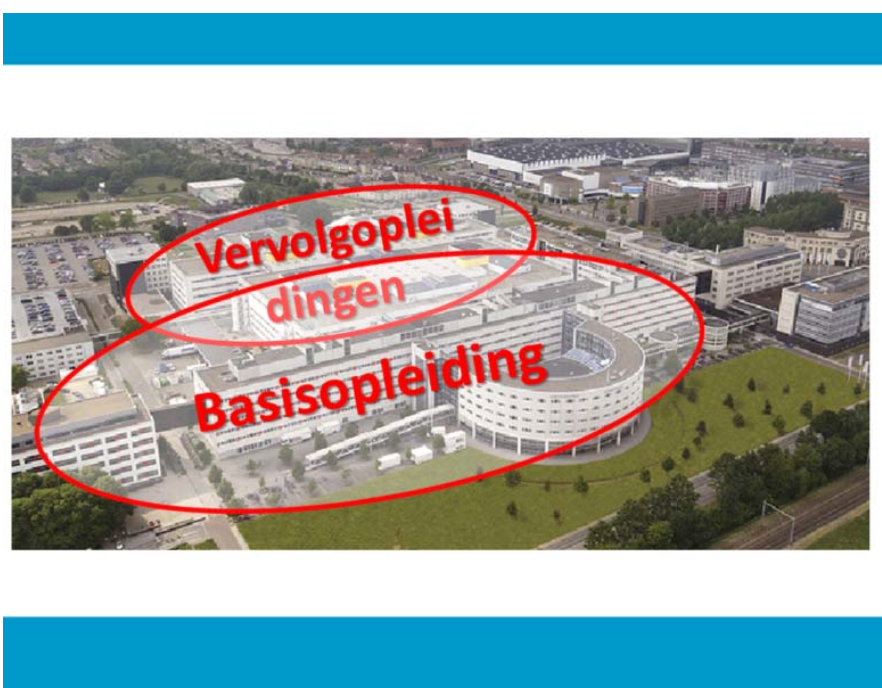

Experts hebben nu eenmaal hun handenvol aan het werk op hun eigen terrein. En strakke budgettering stelt grenzen aan welwillendheid. Gelukkig waren Albert Scherpbier en Kees van der Vleuten zo visionair dat zij al vroeg expertise uit de basisopleiding boden aan de specialistische wereld. En gelukkig was de Raad van Bestuur van het MaastrichtUMC zo professioneel om een apparaat op te tuigen om deze samenwerking vorm te geven: het Directoraat Medische Vervolgopleidingen waar ik leiding aan mag geven. Hierin geven onderwijskundigen, beleids- en stafadviseurs en secretariaat het opleidingsbeleid gestalte.

Dit directoraat vervult ook de functie van expertisecentrum voor de regio. Onze opleidings- en onderwijs regio, de OOR ZuidOost Nederland heeft een bestuur en diverse commissies waarin bestuurders, opleiders en onderwijsgevers goed samenwerken en regionale opleiding en onderwijs vormgeven. Toch wordt er soms naar de academie gekeken voor advies. 


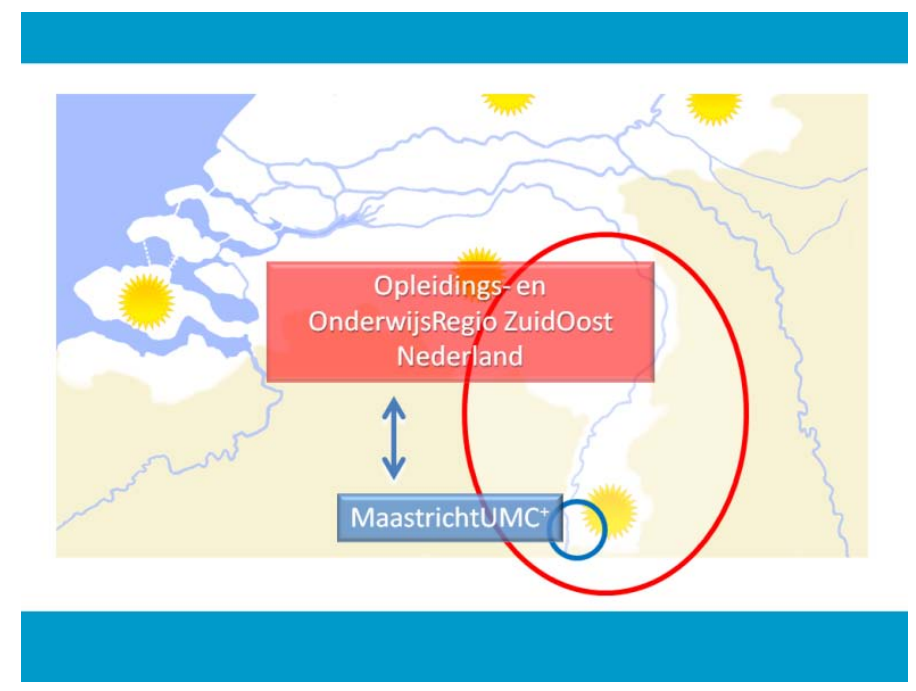

Over kwaliteitsbeleid, over opzet van discipline overstijgend onderwijs en meer. Die taak nemen wij graag op ons. Het past in deze tijd van doelmatigheid dat wij onze expertise ter beschikking stellen en we elkaars ervaring gebruiken.

Ik wil nog een zorg met $u$ delen. Het zal niemand zijn ontgaan dat de huidige regering 270 miljoen wil bezuinigingen op de opleiding tot medisch specialist. Ook hier moeten we samenwerken om de juiste koers te bepalen.

De minister denkt immers dat de opleiding tot medisch specialist beduidend korter kan. De vraag is hoe gevaarlijk het is om, terwijl de invoering van het moderne opleiden nog niet eens voltooid is, de volgende verandering af te dwingen. Realiseert u zich ook hoe compleet en veilig onze opleiding is. Het systeem van visitaties, kwaliteitscontrole en learning on the job kent in Europa zijn gelijke niet. Zelfs in Duitsland en in Belgie leert de chirurg zelfstandig opereren voor een belangrijk deel pas na zijn opleiding waarbij de veilige omgeving van coaching en feedback door ervaren leermeesters niet meer gegarandeerd is.

Toch hebben wij een gezamenlijke verantwoordelijkheid om mee te werken aan zo'n bezuinigingstaak. Het gaat immers om geld voor de gezondheidszorg als geheel.

Ik noemde al hoogleraar Ton de Goeij. In zijn oratie houdt hij er rekening mee dat de studie geneeskunde korter wordt en een deel van de masterfase naar de bachelorfase zou kunnen verschuiven, of naar de vervolgopleiding. Een landelijke gedachte is om de overgang van de medische studie naar de vervolgopleiding te versnellen. In de heelkunde bijvoorbeeld zit gemiddeld een periode van 3 jaar tussen afstuderen en de start van de opleiding tot specialist. In deze periode kiest de jonge dokter zijn vak en opleiders kiezen de geschikte kandidaten. Het idee is om deze selectie zich al in het laatste studiejaar te laten afspelen, in een zogenaamd schakeljaar. Dit vraagt van de aankomend arts een zeer vroege keuze en van de vervolgopleiders bereidheid en kunde om al in deze fase te selecteren. Deze uitdagingen zullen faculteit en vervolgopleiding samen aan moeten gaan.

\section{Dames en heren,}




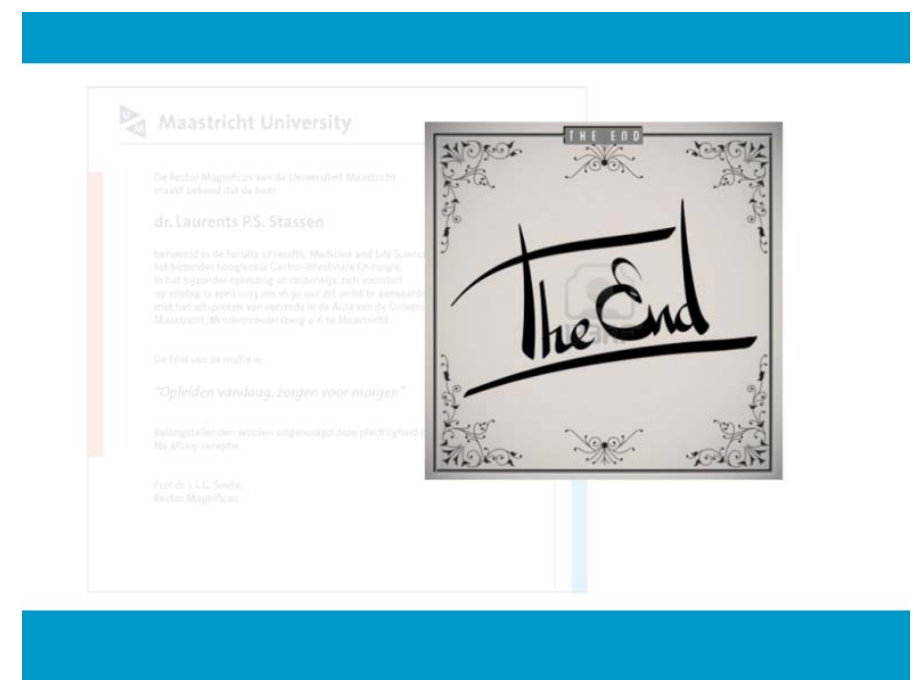

The end is at hand, althans van deze rede.

Ik heb geprobeerd een aantal belangrijke ontwikkelingen in de zorg en in de opleiding voor het voetlicht te brengen. Hoe opleiden vandaag er uit moet zien. Hoe hierdoor de zorg voor morgen mogelijk wordt. Hoe we de aios moeten begeleiden om op die zorg voor morgen voorbereid te zijn. En ik heb een paar zorgen met u gedeeld.

Maar ik heb vertrouwen in de toekomst. Er zijn al vele revoluties geweest. Wij dachten niet dat we opleiding konden geven in een werkweek van 48 uur en toch lukt het. En, als modern chirurgen hebben wij er geen last meer van dat we niet meer èn chirurg èn gynaecoloog èn uroloog tegelijk zijn, zoals onze voorgangers. Integendeel, we beseffen ons dat we ons werk niet goed zouden kunnen doen met zoveel petten tegelijk. De verdergaande differentiatie in de toekomst kan net zoveel plezier geven. Onze zorg mogen wij niet overdragen op de jongeren. Wij zouden hun flexibiliteit en ambitie daarmee onrecht aandoen. Net als wij zullen zij beseffen dat de diepgang die ze willen leveren niet op teveel terreinen tegelijk kan liggen. Het is wel aan ons om hen de handvatten te geven om zich te ontwikkelen. Zo krijgen zij de vaardigheid om hun eigen toekomst en die van de gezondheidszorg vorm te geven.

\section{Tot slot, een woord van dank.}

Velen zijn voor mij belangrijk. Namen noemen betekent ook dat ik namen achterwege laat. Neem mij dat niet kwalijk. Ik sta stil bij een paar fasen van mijn leven en personen met grote invloed op mijn carriere tot nu toe.

Mijn opleiding. Theo van Vroonhoven, Chris van der Werken en Gauke Kootstra, mijn chirurgische meesters. Jullie waren inspirerend, van jullie heb ik het vak afgekeken. Huug Tilanus en Ruud Schouten, mijn vervolgopleiders gastrointestinale chirurgie. Wat een voorrecht onder zulke vakmensen en in zo'n amicale sfeer te hebben mogen werken.

Delft. Mijn maten maar vooral mijn maatjes maagdarmchirurgen Tom Karsten en Peter de Graaf. Wij hebben een mooie tijd gehad. Met elkaar en met onze makkers de MDL artsen. Van hen noem ik met name Clemens Bolwerk en Joost Scherpenisse: voorbeelden van collegialiteit en gedrevenheid. Maastricht. Kees Dejong, Michael Jacobs en Guy Peeters. Jullie zagen het wel met mij zitten als opleider hier.

Martin Paul en Albert Scherpbier, jullie zagen het wel met mij zitten als hoogleraar in Maastricht. Maten chirurgen, ik zag het wel met jullie zitten als collega's: wat hebben wij een prachtige groep. Maagdarmleverartsen, dank voor jullie expertise en vriendschap. Wij houden samen de zuidelijke maagdarmleverzorg op hoog niveau.

Dames en heer van het directoraat medische vervolgopleidingen, jullie leveren kwaliteit. Dank voor jullie niet aflatende inzet. 
Assistenten heelkunde, uit het verleden en het heden. Het is een voorrecht jullie opleider te mogen zijn. Het is genieten om te zien hoe hecht iedere nieuwe assistentengroep weer wordt en te zien wat voor vriendschappen voor het leven er worden gemaakt. Het is een uitdaging om met jullie jullie toekomst vorm te mogen geven.

Verpleegkundigen en alle zorgers in de ziekenhuizen waar ik heb mogen werken: het samen werken en samen het beste willen doen voor onze patiënten maakt ons vak zo mooi. Dank daarvoor.

En nu de belangrijksten. Ik hou het kort, dank voor jullie is niet voldoende in woorden uit te drukken. Mijn ouders, jullie gaven mij alle ruimte om me te ontwikkelen tot wie ik ben. Pap, en Margot, mijn zus, dank voor jullie betrokkenheid tot op de dag van vandaag.

Nicole en Pauline, mijn meiden. Nicole, je hebt me door alle jaren en drukte heen gesteund. Je bent onmisbaar. Pauline, het is heerlijk om te zien hoeveel plezier jij in het leven hebt maar ook hoe jij je ontwikkeld als mens en als dokter. Ik ben trots op je. Meiden, met jullie is het leven mooi, daar gaan we nog lang mee door!

Ik heb gezegd. 